\title{
Die vergelyking en die beoordeling van die toepassing van die integrale kosprysberekening en die differensiële kostekalkulasie*
}

,Flk practisch gebied, dat pas met het theoretiseren begin, vindt theorie doods, zolang deze nog geen gerijpte theoretische takken draagt" (A. C. Elshach: Encyclopaedisch handboek van het moderne denken, Arnhem, 1942, h. 815).

Hierdie toestand van sake is tans in Suid-Afrika waarneembaar. Behalwe Sorgdrager en Viljoen (Leerboek van die moderne kosprysadministrasie, Potchefstroom, 1962) is daar nie juis in ons land in Afrikaans of in Engels oor die kosteproblematiek gepubliseer nie. Veral in SuidAfrika val dit steeds weer op hoe die pragmatiese Angel-Saksiese beskouings die botoon voer. Dis in die lig van die geskiedkundige agtergrond nie verbasend nie, maar dit bied 'n verstarring en weerstand tot 'n eventuele verdere uitbouing van die teorie en praktyk van die moderne kosprysadministrasie. Integrasie tussen teorie en praktyk is tog absoluut noodsaaklik vir die volle ontplooiing van die leer van die kosprys.

Die ondervinding help wel die tegniese uitbouing van die kosprysleer maar wat T. S. Elliot in The dry salvages heweer, kan ook op die kosprysleer toegepas word:

We had experience, but missed the meaning

And approach to the meaning restores the experience

In a different form...

Ons eie N. P. van Wyk I.oılw ŝि tereg in Flegiese Verse (Tristia. Kaapstad, bl, 89):

Nee; tegniek sal ons nooit gebruik nie,

Die mens al kan hy tegniek hanteer,

Hy bly eintlik buite rekening.

Die kosprysgedagte het in Suid-Afrika proefondervindelik tot stand gekom en dit staan sterk onder invloed van die Angel-Saksiese literatuur, wat die leer van die kosprys as 'n bepaalde tegniek, sonder 'n teoretiese

\footnotetext{
* Inougurele rede gelewer by die aanvaarding van 'n professoraat in die Koste herekening aan die P.I. vir C.II.O., deur dr. A. J. F. Sorgilrager, op 15 Maart 1963.
} 
en analitiese opbou, beskou. Met hierdie standpunt kan die kosteberekenaar hom uiteindelik nie meer vereenselwig nie, soos in die loop van die betoog uiteengesit sal word.

Dit het die outonomie van die wetenskap en die teoretiese denke verbreek. Die kosmiese wet setel ook in die subjek, daarom moet die irrasionalisme ook subjektief wees. Dit is onaanvaarbaar. Die grondslag van die irrasionalisme is die'werklikheid, die praktyk, so word deur die aanhangers van dié skool, o.a. die pragmatiste, beweer. Noudat die filosofie nie meer in dic vlak van die teorie en die denke is nie, moet daar ' $n$ ander houvas gesoek word. Die strooihalm waaraan nou vasgeklou word, is die tegniek en die praktyk, die praktiese handelinge van die lewe. Die swaartepunt word na die sg. ateoretiese subjek van die ervaring verplaas, die eksistensie, waarin die wet van die werklikheid oorheers.

Die pragmatistiese skool is in hoofsaak 'n Amerikaanse skool. Die pragmatiste gaan van die idee uit dat slegs feite die wetenskap en die filosofie beheers en dat met die formulering van bepaalde wette die sentrale praktiese nut die grondslag moet vorm. Die feite moet dan tot 'n teorie omgewerk word (vgl. W. James, 1842-1910: Pragmatism. James, wat die grondslag van hierdie opportunistiese denke gelê het, beweer dan ook: ,You want a system that will combine both things, the scientific loyalty to facts, and willingness to take account of them, the spirit of adaptation and accomodation" en verder ,it is a method only" (op. cit., bl. 151).

Die pragmatistiese denke is in Groot-Brittanje as humanisme geïtroduseer (vgl. D. S. Mackay: Pragmatism in V. Fern: A history of philosophical systems, bl. 388). Daar kan met reg beweer word dat die .,meaning" ontbreek en ,die mens, hy bly eintlik buitc rekening”. W. Prion (Die Lehre vom W'irlschaflsbetrich, Berlyn, deel I, s.j., bl. 135) het tereg beweer dat so 'n opvatting slegs 'n kunsleer is.

Dit is kontra my persoonlike opvatting in objekticwe sin, dat 'n wetenskap, geheel en al, sistematies, in onderling samehangende waarhede bestudeer moet word. Dit vereis 'n geordende, afgeronde patroon, 'n studie van die totaliteit waaraan 'n wetenskap as afsluitende leer, moet voldoen. Van die standpunt word uitgegaan dat die begrip wetenskap 'n abstraktiewe begrip is, slegs as term vir die wete in die sin van kennis van wat algemeen en noodsaaklik is in teenstelling tot die nienoodsaaklike algemeenhede en pure feitekennis. Hierby sal dan as wetenskap na vore tree die kennis wat uit beskrywing en analise van 'n bepaalde kenobjek gesintetiseer is. Dit moet die waarheid in algemene noodsaaklikheid dien. 
In gemeen met alle praktiese wetenskappe wat hulle besig hou met individuele objekte en verskynsels waarmee die mens daagliks in aanraking kom, het die problematiek van die kosprysleer 'n objek van studie geword omdat die mens hierdie kennis wou aanwend vir nuttige gebruik in die onderneming. Sedert die Industriële Revolusie waarin die verskille in die maatskaplike voortbrenging geaksentueer is, het die vraagstukke rondom die leer van die kosprys al meer op die voorgrond getree.

Die kleinste eenheid wat aan die matskaplike voortbrenging tot grondslag lê, is die mens. Die mens is met verstand begiftig en dit stel hom in staat om te kan differensieer en 'n keuse te doen. Hier ontstaan die problematick oor die keuse van die middels en die toepassing van hierdie middels in die daaglikse gebruik. Maar die mens gebruik sy verstand, hy beraam en begroot en eers daarna gaan hy oor tot die uitvoering van sy besluit en besien die resultaat van sy keuse. Die ex post word met die ex ante vergelyk. Dit is wat die Duitsers die Sollen Ist-begrip noem.

Die mens organiseer eers en meet daarna die resultaat waarmee die grondslag van die moderne bedryfsopvatting vasgelê is. In die normatiewe opvatting word daar 'n noue relasie tussen organisasiestruktuur en kostestruktuur gelê. Die verbesondering van die koste moet dan die organiese struktuur volg en die kosprys moet die rasionaliteit van die organisasiestruktuur toets.

Oor die begrip wetenskap is daar al baie gediskusseer. Daar is verskillende betekenisse wat die begrip wetenskap omsluit. Die wetenskap staan voor die probleem om te skei wat vir skeiding vatbaar is en saam te snoer wat hy mekaar hoort. Verskillende wetenskappe kan bepaalde begrippe en objekte gemeen hê sonder om hulle eie identiteit prys te gee. Dit is hier noodsauklik om te konstateer dat die wetenskap integraal is, ondeelbaar is, dat die wetenskap in sy geheel die waarheid is wat by God herus (vgl. Joh. 14: 6 , Ek is die weg en die waarheid en die lewe). Die mens, met al sy kennis, sal nooit die samehang oorsien nie. Die Switser, J. Spieler (Finführung und Anleitung zu wissenschaftlichen Denken und Arbeiten. Olten, 1946, bl. 27) het hierdie relativiteit van die wetenskap nog nader toegelig deur te sê daar bestaan slegs een wetenskap wat die werklikheid in gedagte probeer na te bou en wat sigbaar in die boek van die werklikheid uitgedruk word, nl. die filosofie. Deur die beperktheid van die mens maak die een wetenskap na die ander hom van die filosofie los. Die filosofie is vandag nog die enigste wetenskap wat hom op die totaal ingestel het (vgl. verder J. A. L. Taljaard: „Die mnes, die liefde en die sedelike", herdruk uit Koers 1956, bls. 3, 4 en 5). Daarom kan geen vakgebied uit die gehele werklikheid differensieel geneem word nie. Dis organies met die geheel verbind en los van insidentele improvisasie. 
Daarom kan die een orgaan nie oor die ander heers nie (vgl. 1 Kor. 12 : 21). Paulus sê ook daar is geen gelykheid in organe nie, wat nie beteken dat die een minderwaardig an die ander is nie. Hulle is net verskillend en hulle vorm saam een liggaam met eenheid ondanks die verskeidenheid van organe (vgl. Sorgdrager en Viljoen, op. cit., bls. 158 en 159). Die antwoord op die vraag hoe die organiese bou en struktuur van die onderneming moet wees, word hier aangetoon.

In die praktyk blyk dit dikwels maar al te duidelik dat van die noodsaak van die genoemde ewewig geen rekenskap gegee word nie. 'n Organisasie wat met die ewewig en sy spesifieke karakter rekening hou en so opgebou is, het die verantwoordelikheid vir die gang van die onderneming in al die gedifferensieerde onderdele kwalitatief bepaal.

H. J. van der Schroeff beweer tereg (Leiding en organisasie van het bedrijf. Leiden, 1961, bl. 234) dat die organisasiebegrip 'n doelbewuste handeling aandui. Saamvallende met die organisasie is daar die arbeidsverdeling (vgl. Gen. $4: 20-22$ ) wat saam met die kostemotief 'n rol speel (vgl. H. J. van der Schroeff, op. cit., hl. 306 en H. J. Kruizinga: De orgunisatiestructuur van het bedrijf. Leiden, 1953). Indien al die arbeid deur een mens verrig sou word, sou dit 'n ongunstige kosteverhouding skep. Daar lê 'n kostevoordeel in as hoër en laer gekwalifiseerde arbeid geskei word. Daar dien op gelet te word dat slegs na 'n ekonomiese waardering verwys word. Laer gekwalifiseerde arbeid beteken eenvoudig dat die arbeidskrag met 'n laer vervangingsprys verrig kan word. Tog moet in die lig van bogenoemde die organisasie van die ekonomiese arbeidstruktuur sodanig geskied dat met 'n opbou van arbeidstake hulle gelykwaardig aan mekaar is, m.a.w. wat 'n gelyke vervangingswaarde besit. I)ie benadering is nog steeds integraal.

Nou het die wiskundiges ook die term integraal. Dit het in daardie vakgehied ook 'n spesifieke betekenis. Daar kan mee saamgestem word dat die gebruik van woorde wat vir meer as een vakkundige betekenis vathaar is, hestry moet word maar die vraag bly altyd weer watter vak motet kopgee. Die heskikbare woordeskat van die mens is te klein om dit differensieel vir ' $n$ bepaalde wetenskap te reserveer. Die heswaar is veral geldig omdat die verskillende begrippe vir die onderskeie wetenskappe uit verskillende gesigspunte gevorm word. Omdat die leer van die kosprys 'n baie jong wetenskap is en tal van woorde reeds in gebruik by ander wetenskappe is, is daar altyd die gevaar van verwronge en ondoelmatige woordkonstruksie. Die gewoonte om klakkeloos uit Engels te vertaal sonder om die inhoud van die woorde eers te verken, moet ook streng afgekeur word. Daarom moet die woord - integraal - ook nie met die Engelse „integral" (soos o.a. gebruik in „integral cost accounting”) verwar word nie. Daar het dit bloot die betekenis van intra-komptabele verslaglegging, m.a.w. 'n samesnoering van koste en rekenkundige verslae. 
Dic kostemotief moet as beslissende element in die opbou van die organisasie gesien kan word. Dic kosteberekening sowel as die kostebeoordeling spcel hicrin 'n baic belangrike rol. In die gedagtegang is 'n normatiewe grondslag opgencem en wel dat alleen wanneer 'n offer doelmatig aangewend is, kan daar van koste gepraat word. Hierdie aspek word deur die sosiaal-ckonome tot 'n baie groot mate verwaarloos. Ook dic rekenmeester maak die denkfout om die rekenkundig-tegniese vraagstuk as kosprysprobleem te sien. Vandag nog word die grootte van die offer (van kosprys kan nie gepraat word nie), as 'n probleem van rekenkundig-tegniese aard gesien. Dit het die ontwikkelingsgang van die leer van die kosprys baie vertraag en vertraag dit nog. Dit verklaar ook die opkoms van dic differensiële kostekalkulasies in Suid-Afrika omdat die kosprysprobleem op dic koopmansboeklouding afgestem is, wat natuurlik al klaar weer 'n misvatting is. Jie verwarring van die individuele ondernemer word 'n ernstige gevaar indien by die soek na 'n oplossing die die keuse van die middels afhanklik van die koopnansbockhoudingrcëls gemaak word. Die liedendaagse koopmansbockhouding gee as middel tot wataneming omtrent die wese en die elemente van die kosprys 'n volsirekte miskenning. Daarom is dit noodsaaklik dat die rekenmeester suwcl as dic sosiaal-ckonoom hulle rckenskap gee dat deur middel van dic oorsaaklike verband die juiste elemente van die kosprys opgespoor word om tol 'n korrekte insig oor die wese van dic offer en sy elemente tol dic grootte van die kosprys te kan kom.

Veral vir die sosiaal-ckonoom is dit van belang. Die waarneming binne die onderneming word aan hom onttrek. Behalwe vir die gepublisecrde state van openbare ondernemings, waarin uit die aard van die saak so min as moontlik bekend gestel word, word die deure en vensters van die onderneming figuurlik so veel as moontlik gesluit. Die waarnemingsmateriaal ter beskikking van die sosiaal-ekonoom is baie min, en hy raak van die ondernemingsverskynsels vervreemd. Die inwendige bou en organisasic van die onderneming raak vir hom onbekend, hy verstaan nie die terminologie nie en die koopmansboeklouding is vir hom 'n onbruikbare instrument. Hicrdeur vervreem hy van sekere oorsaaklike verskynsels, met die gevolg dat daar o.a. oor die differensiële kostekalkulasic sulke wanopvattingrs bestaan.

Dat die sosial-ekonoom hom tot dusver nog nie juis met die kosprys bemoei het nic, spruit uit dic algemene gedagtegang dat die waarde van 'n ecnheid nie bepaal word deur dic offers by die vervaardiging van die cenlicid nic maar deur die offers wat die koper tot bevrediging van sy begecrte om die besit daarvan wil bring. Die gevolg is dat die sosiaalekonoom aan die kosprỵs slegs 'n sekondêre rol by dic algemene prysvorming tocken. Daarom is dit nodig om rekenskap te gee van wat onder dic offers wat dic kosprys vorm, verstaan word. Geruime tyd en vandag 
nog word gemeen dat die koste van voortbrenging of vervanging deur die som van die geldoffers wat daaraan bestee is, bepaal word. Hierdeur het koste en gelduitgawes sinoniem geword, bloot 'n rekenkundige begrip. Die fout lê hierin dat die boekhouding deur omstandighede as 'n geskiedskrywing bestempel word, met die gevolg dat aan die kostebegrip ook 'n geskiedkundige interpretasic gegee is.

So lank as daar ' $n$ uitgawe gedaan is wat in die boekhouding geregistreer is, is daar van koste sprake. In die algemene spraakgebruik word onder koste immers ook geldoffers verstaan. Natuurlik is 'n dergelike kostebegrip vir die ondernemer self besonder naïef. Offers wat nie doelmatig aangewend is nie behoort nie tot die produksiekoste nie maar moet as verspillings aangereken word. Iedere offer wat, beoordeel vanuit die ekonomiese motief, nie verantwoord is nie, is 'n verspilling.

'n Verbetering is alreeds deur die invoering van standaardkoste te bespeur. Daar word egter nog aan die uitgaafyedagte vasgeklou en daarom is die normkosprysgedagte ingevoer. Daar moet vasgestel word dat daar in die literatuur van die sosiaal-ekonome nie van die gelduitgawegedagte losgekom word nie. Dit geld veral dic ckonome wat hulle teorieë op die grensnutwaardeleer gevestig het.

Namate die kostebegrip tot volle ontplooiing gekom het, het die opvatting verwerp geraak. Teenoor 'n uitgawe hoef nie 'n koste te staan nie, en daar is kostefaktore waar geen uitgaaf teenoor staan nie. Vir die kostebegrip is dit nie van betekenis of daar geldoffers gemaak is nie maar wel of daar in die produksie waarde opgeoffer is om die produk te kan vervaardig. Ook Schmalenbach het die opmerking gemaak: „Das Verzehren, nicht das Geldausgaben, entscheidet".

Hierdeur is die kosprys nie langer 'n rekengrootheid wat insidenteel vir 'n gegewe doel bereken word en in grootte varieer na gelang die doel waarvoor die berekening bcoog word nie (vgl. M. Clark: The economics of overhead costs. Chicago, 1923).

By 'n kwantitatiewe gelykheid tussen waarde en kosprys kan die kosprys van die eenhede rie verskillend wees nie. Dis in teenstelling met die gangbare opvatting in Suid-Afrika met as grondslag die uitgaafprys, dat daar verskille in grootte van die kosprys optree al na gelang die verbruikte produksiemiddele, grondstof en arbeid wat aangewend is, varieer. Deur die relasie wat daar tussen kosprys en waarde heers, is hierdie opvatting onjuis. Koste is alleen die offers wat ekonomies onvermybaar en tegnies noodsaaklik vir die vervaardiging van die produk is. Dis logies dat die ondernemer moet weet wat sy produk werd is ten einde te kan vasstel wat hy ten offer bring by die ruil en wat hy aan verteerbare inkomste uit die ruil verkry het. Sonder behoorlike kennis 
van waarde is daar geen rasionele produksie nie. Sonder behoorlike kennis van die integrale kosprys weet die ondernemer nie of sy ruil, en dus die produksie, rasioneel is nie. Aangetoon is reeds dat kosprys en waarde, hoewel van mekaar geskei as begrippe, in grootte aan mekaar gelyk is. Die vraag wat nog opgelos moet word, is wat die waarde van die eenheid op die moment van die ruil is. Die antwoord is normaliter die vervangingswaarde, d.w.s. die waarde gemeet aan die vervangingskoste van die eenheid. Die waarde-oordeel vorm die grondslag van die mens se produktiewe handelinge. Hierdie houding of daad skep dan alleen ekonomiese voordeel wanneer die waarde wat geruil kan word die opgeofferde waarde oortref. $O_{p}$ grond darvan moct die koste wat in die totstandkoming van 'n eenheid aangegaan word, na die waarde van die middele wat by die produksie lenordig is, gemeet word. Die kostebegrip is hiermee bepaal. Koste is die walarde-eenhede wat vir die produksic opgeoffer moet word om nuwe waarde to kan verkry. Koste sonder waarde is nie denkbaar nie. Geen eenheid kan waarde besit indien die opoffering nie met koste gepaard gaan nie. Waarde en integrale koste vorm die kritiese maatstaf waarmee die doelmatigheid van die ekonomiese handeling gemeet word. Indien hesel word dal in 'n ondersock die doelmatigheid van die handeling in dic produksic vanuit 'n ekonomiese motief beoordeel moet word, dan is die sentrale plek wat die kostebegrip in die onderneming inneem, sekerlik verstaanbaar.

Die opvatting het 'n einde gemaak aan die tegniese koste-opvatting van die Augel-Saksers, wat nie rekening hou met die, as gevolg van 'n dinamiese ekonomie, immer wysigende prysverhoudings nie. Dat die kosprys uit historicse data opgebou moet word, word dan dus deur die vervangingswaardeteorie verwerp. Dit kom slegs in naam met die oorspronklike kostegedagte ooreen.

Langs die vervangirgswaarde moct daar ook nog 'n opbrengswaarde wees want goedere wat geen opbrengswaarde het nie, het geen waarde, dus geen vervangingswaarde nie. Die apprioristiese oordeel van die bekende opvatting in Suid-Afrika is dat die teorie van die vervangingswaarde beweer dat die waarde-oordeel omtrent 'n eenheid op enige moment steeds bepaal word deur die vervangingswaarde. Daar is twee matstawwe waarmee gemeet word, opbrengswaarde en vervangingswaarde, wat in onderlinge integrale samehang beskou moet word en waarvan die laagste van die.twee, die deurslag gee.

Daarom is tot dusver gepraat van kosteberekening en nie van kosprysberekening nie. Vermenging van die begrippe lei daartoe dat die funksie van die kosteberekening te beperk gehou word. Die kosprys dien:

1. as grondslag vir die prysbepaling (die kosprys is slegs een van dic ekonomiese grondslae; ook die ekonomiese date van die vraagkant speel 'n belangrike rol); 
2. vir dic bepaling van die ondernemersresultaat, m.a.w. die verskil tussien ophrengs en kusprys;

3. tot die beoordeling van die ekonomiese doelmatigheid van die produksic. Die doelmatigheidsbepaling is op die verbesondering van die kosprys gebaseer, waardeur ondoelmatige arbeid, ondoelmatig aangewende masjinerie en materiaal en ondoelmatige indirekte koste aan die lig kom. Doelmatigheid kan beskou word as die verhouding wat daar tussen „output" en ,.input" heers. Dit hepaal die kousale relasie. Met die steeds toenemende meganisasie en outomatisasie speel veral die indirekte koste '" steeds belangriker rol, omdat die direk annwysbare verband van die direkte koste in verhouding tot dic indirekte koste aan die afneem is.

Ook (;. Shillinglaw (Cost accounting, analysis and controle. Illinois, |'(1, b. 9) het nal die vermenging van begrippe verwys. Hy beweer die term ,cost accounting is perhaps misleading, because the subject no longer confines itself to accounting for costs. A more accurate description is provided loy the term managerial accounting, as may be seen in contrast to financial accounting or enterprise accounting".

Die beoordeling van die ekonomiese doelmatigheid moet derhalwe nie as 'n funksic van die kosjprys gesien word nie. Die doelmatigheid word nie beoordeel aan die kosprys van die kostedraer nie maar veral deur die doelmatigheidsvariasies van die normkoste tecnoor die werklike offers van die produksie te stcl. Dic aksent word na die koste van die deelverrigtings verplaas, waardeur die beslissingselement meer op die voorgrond tree. Die kostcherekening lê meer klem op:

1. Die grondslag vir die neem van besluite.

2. Die grondslag vir die beoordeling van die ckonomiese doelmatigheid.

3. Dic grondslag vir dic kalkulasie van dic lotale eindresultaat.

Die problematick van die koste-analise het hicrmee sterk op die voorgrond getree. Dit belicls kalkulasieskemas. Daar moet aan 'n organiese teenoor 'n kostegroepering gedink word. Die kostegroepering is van belang om die helangrikheid van die verskillende kostesoorte met mekaar te vergelyk. Dit het weer sy invloed op die organiese, soos o.a. materiaalheheer.

Dic organiese groejering van koste is gerig op die bestemming van die koste, onderverdeel in kostesoorte en aangetoon in kostcplekke of 'n sentrun van verantwoordelikheid.

Die verbesondering in die produksie en distribusie kan weer in twee hoofvorme onderskei word, die spesialisasie en die differensiasie. Die onderskeid lê hierin dat die spesialisasie die saamtrek van alle werksaamhede wat op 'n bepaalde produk of groep produkte betrekking het is, terwyl die differensiasie op die doelbewerkinge wat die produk van 
grondstof tot eindproduk vorm, toegespits is. Spesialisasie is die verbesondering op die kategorie van produk, differensiasie op die kategorie van hewerking. Die uitken van die struktuur is van fundamentele betekenis en is noodsaaklik vir die leiding en beleidsvorming, doelmatigheidsbeoordeling, kalkulasie en analise van resultate en prestasie is.

Daar dien op gelet te word dat kosteplekke en sentrum van verantwoordelikheid nie altyd as identies beskou kan word nie. Die kosteplek is 'n organiese eenheid, maar die sentrum van verantwoordelikheid word aan 'n persoon gekoppel. Die kosteplek is as organiese eenheid die plek waar die koste verbesonder word met die uitdruklike bedoeling om die prestasies op daardie plek te leer ken. Die kosteplek is bedoel om 'n noue relasie te kan lê tussen die koste en eenheidproduk wat in die organiese verbesondering inpas. ' $n$ Sentrum van verantwoordelikheid is 'n personele verbesondering en lê die relasie tussen die verantwoordelike funksionaris en sy koste binne die grense van sy verantwoordelikheid. Die kosteplekke word as tussenfase in die verbesondering van die koste na die kostedraer heskou. Hierdie verskil is ook nie. deur J. H. Higgings in Responsibility accounting (The Arthur Anderson Cronicle. 1952, in W. E. Thomas: Reaulings in cost accounting, budgeting and control, N.Y., 1955, bl. 101) aangetoon nie.

C. Scholma (Kostencalculatie in het bedrijf, 2e druk, Alphen aan den Rhijn, 1961, bl. 14) het nog 'n verdere indeling na aanleiding van die rubrisering van koste na verskillende gesigspunte, o.a. na die funksionele splitsing (fabrikasiekoste, verkoopskoste en algemene koste) in relasie tot die produksievolume (variabele koste, semi-variabele koste en vaste koste) en in relasie tot die kalkulasiemetodes (direkte en indirekte koste).

Scholma se benadering is 'n tipiese voorbeeld van die begripsverwarring wat daar in die kosteproblematiek heers, want sy begrippe word nie duidelik uiteengesit nie. Tereg merk $\mathrm{A}$. Walther (Einführung in die Wirtschaftslehre der Unternehmung, deel I, Zürich, 1947, bl. 227) op dat ,es ist üleerhaupt erstaunlich, wie wenig genau wir Betriebswirtschafter es mit der Logik genommen". Die oorsaak is die feit dat die sosiaalekonome, die rekenmeesters en die bedryfsekonome almal die leer van die kosprys doseer, elk met hulle eie terminologie en eie betekenis wat hulle aan die terminologie heg. 'n Samesnoering tot 'n logiese eenheid sal die ekonomiese wetenskappe slegs ten goede kom.

In die jongste tyd het die tegniek van die differensiële kostekalkulasie sterk op die voorgrond getree. Veral in Amerika neem hierdie tegniek, want dit is niks anders as 'n tegniek nie, groot afmetings aan. Persoonlik heskou ek dit as terugplasing van die klok na die begintydperk van die Industriële Revolusie. Die metode staan in die V.S.A. as „direct 
costing" bekend. Nuut is dit nie, omdat die tegniek lank reeds in die vakkgebied bekend is. Die metode het in die brandpunt van die belangstelling gekom deur 'n verslag wat in 1953 deur die „National Association of Accountants" uitgereik is. Sedert 1953 het daar 'n uitgebreide literatuur tot stand gekom wat in R. Slot se Kostevariabiliteit en variabele kosteculculatie (Leiden, 1962) die hoogtepunt bereik het. Die grondslag van hierdie tegniek is die gedrag van die koste t.o.v. die omvang van die produksie, Die grenskostekalkulasie gee aan hierdie verskille 'n besondere betekenis. Die grenskostemetode kan omskryf word as die metode van kosprysberekening waarby slegs die variabele, koste, ten laste van die kostedraers of kalkulasie-objekte gelê word. Die konstante koste wat nie van die omvang van die produksie nie maar van die omvang van die kapasiteit van die .verskillende produksiemiddele afhanklik is, word nie na die kostedraers verbesonder. nie maar regstreeks as een bedrag ten laste, van die vervaardigersrekening gelê.

In die Amerikaanse taalgebruik word daar 'n onderskeid getref tussen "product costs" (dis die variabele koste) wat afhanklik is van die omvang van die produksie en afset, en die ,period costs" wat slegs met verloop van tyd afhanklik is maar van die omvang van die produksie onafhanklik is. Slegs die sg. ,product costs" word in die kalkulasie van die kostedraers opgeneem.

By die variabele koste word van die veronderstelling uitgegaan dat dit proporsioneel variabel is en dat die vaste koste die totale bedrag van 'n bepaalde periode is wat onafhanklik van die produksieomvang van die periode is. Die gemengde.koste en die trapsgewyse variabele koste word deur ' $n$ kunsoplossing na een van die genoemde vaste of variabele koste toegedeel. Daarom word die term variabele kospryskalkulasie ook in die ,direct costing"--metode gebruik. Die Britse ekwivalent vir ,direct costing" is „marginal costing”. Selfs onder die Angel-Saksers is daar dus verskil in terminologie.

Teenoor die verkope van 'n bepaalde periode word slegs die variabele koste gestel. Die voorraad op hande asmede die goedere in bewerking word op die variabele koste gewaardeer. Die periodewins hou geen verband met die produksieomvang nie maar met die verkope. Die leiers van die onderskeie kosteplekke is slegs verantwoordelik vir. die variabele koste en dra geen verantwoordelikheid vir die vaste køste nie.

' Die verskil tussen die omset en die variabele koste word deurgaans as „marginal income, profit contribution, contribution margin, direct margin, cash margin, marginal balance" of "variabele gross margin" aangetoon. In party handboeke, o.a. Accountants' cost handbook, bl. 18-21 (vgl. Slot, op. cit., bl. 79) word daar 'n verskil tussen „contribution 
margin" en „marginal income" getref. "Contribution margin" is gelyk aan „marginal income" met direkte koste verminder.

Bogenoemde metode kan as grondvorm van baie kalkulasiemetodes beskou word. Daar is 'n groot aantal variante. 'n Bekende variant is om nie alleen die konstante koste nie maar ook 'n deel van die variabele koste direk na die vervaardigingsrekening te debiteer, en wel daardie deel wat baie moeilik is om na die kostedraers te verbesonder. Omgekeerd is dit ook die geval dat 'n deel van die konstante offers na die kosteplekke verbesonder word en die res na die vervaardigersrekening gedebiteer word.

Verder moet die aandag op die woord „costing” gevestig word. By die metode word van die standpunt van offers uitgegaan in die sin van historiese uitgawes wat ook in die literatuur as ,out-of-pocket expenses" bekend staan. Die tegniek word ook herhaaldelik toegepas in kombinasie met 'n stelsel van standaardkosteberekening, veral op die gebied van kostebewaking en kostebeheersing. Die standaard is gewoonlik op die uitgaafbasis bereken.

Schmalenbach (op. cit.) het reeds in 1900 onderskeid getref tussen „Mengekosten” en „Zeitkosten”. „Direct costing” word ook soms gelyk gestel met „marginal costing” (vgl. F. C. Lawrence en E. N. Humphreys Marginal costing. Londen, 1947) of differensiële koste (vgl. D. R. C. Halford Differential cost and management decisions. Londen, 1958). In die Duitse literatuur word daar weer 'n relasie tussen „Grenzkosten” en „Grenzplankostenrechnung” (vgl. W. Kilger Flexible Plankostenrechnung. Köln, 1961) gelê. In die praktyk word daar 'n verskeidenheid terme gebruik soos ,direct costing, variable costing, basic cost, marginal costing, differential costing". Al hierdie metodes differensieer nie hulle konstante offers na die kostedraers nie. Die reeds genoemde integrale kostekalkulasie, gebaseer op deursnee-offers, word in die Angel-Saksiese literatuur met „full costing, total costing” of „absorbtion costing” aangedui, waar die konstante offers wel in die kalkulasie opgeneem is.

Dat differensiële kostekalkulasie so opgang gemaak het, is toe te skryf aan die volgende redes:

1. Die metode bied maklike geleentheid om vinnig tot 'n besluit te geraak.

2. Die metode bied 'n maklike administratiewe bewerking van syfers en kalkulasiemetodes.

3. Die metode bied 'n noukeurige inkomstesyfer vir 'n bepaalde periode aan.

Die differensiële kostekalkulasie moet veral as 'n reaksie teen die in die praktyk te ver deurgevnerde kosteverdeling gesien word. 
By die toepassing van die integrale metode moet daar besluit word in hoeverre dit nuttig is om aan te gaan met die koste wat moeilik te verdeel is. Prakties moet nie verder gegaan word as wat vir die kosteinformasie en -beoordeling noodsaaklik geag word nie. Die differensiële kalkulasie gaan te ver om al die konstante offers nie deur te kalkuleer nie, ongeag of daar wel of nie voldoende objektiewe maatstawwe van verbesondering toegepas sou kan word.

Daar moet egter 'n verskil tussen marginale en differensiële koste getref word. Die differensiële koste het 'n eie spesifieke karakter en betekenis. Die integrale koste is reeds nader omskrywe as die koste wat sonder enige uitsondering noodsaaklik met mekaar in die organiese struktuur van die onderneming verbind is. 'n Beperkte oorsaaklike verband het aanleiding gegee tot die begrip differensiële koste, waarin dit die koste behels met daardie deel van die voortbrenging wat slegs tydelik en insidenteel aan die orige produksie toegevoeg is. Die verskil met die grenskosteberekening is wel duidelik aangetoon hoewel beide begrippe die uitskakeling van die vaste offers, hoewel in 'n ander verband, in gemeen het. So kan die koste van 'n kosteplek differensieel as integraal beskou word. Dit verskil weer van die beskouing in die sosiale ekonomie dat marginale of grenskosprys teenoor die gemiddelde kosprys geplaas moet word. In hierdie betoog word daar nie verder op ingegaan nie.

Die differensiële kostebeskouing is egter nie gebonde an die aanbiedingsprys nie. Die gebruik is om 'n deel van die voortbrenging selfstandig, dus nie organies nie, in oënskou te neem. Die differensiële beskouing is ' $n$ tydelike en tot 'n sekere mate 'n insidentele grondslag vir die aanbiedingsprys van bepaalde dele van die voortbrenging onder bepaalde omstandighede. Die marginale of grenskostekalkulasie word min of meer 'n permanente grondslag vir die aanbiedingsprys of bedryfs. politiek. Hierdie kenmerke vorm 'n onversoenlike teenstelling wat 'n onderskeiding van die twee begrippe absoluut noodsaaklik maak.

Die gevare van die differensiële kostebeskouing is groot. Begryp kan word dat dic produksie-omvang op 'n te hoë vlak gehandhaaf word, met die gevolg dat 'n moontlike kostebesparing op die kapasiteitskoste verwaarloos word. Die differensiële produksie-omvang lê ook beslag op 'n beperkte middel, nl. geld, wat benodig is vir die ekstra inkope aan materiaal, ens. waardeur die normale finansiering van die normale produksie belemmer word. Daarom is dit in tyd van geldskaarste dikwels nodig om produkte te vervaardig met geringe kapitaaluitleg en 'n laer winsgrens as die omgekeerde. Deur die differensiële kostekalkulasie word die aspek taamlik verwaarloos. Daar moet skerp toesig gehou word dat met differensiële produksie die aanwending van 'n skaars produksiemiddel of kapitaal nie oormatig is nie. Dit kan knelpunte in die normale 
produksievloei veroorsaak, waardeur daar 'n hoë verspillingsfaktor sal optree. Dit affekteer die kontinuïteit van die onderneming.

In die praktyk word gewoonlik geen studie gemaak van watter produksiemiddel in die addisionele produksie aangewend moet word nie. Elke bestelling word maar aanvaar, ongeag die vraag watter kapasiteitsonderdele in beslag geneem word. Die grootste gevaar is egter dat die verkoopsdepartement vrywel 'n blanko tjek kry om iedere bestelling maar te aanvaar met moontlike prysbederf as gevolg.

Die gevaar van prysbederf volg op onjuiste kosteberekening. Die uitgangspunt is die redenasie dat die differensiële kosprys die minimum is waarteen die ondernemer kan ruil. Die ondernemer sal op die minimum die grootste moontlike winsopslag lê. Die winsopslag is van die marksituasie afhanklik. Hierdie bepaling van die winsopslag behoort nie meer tot die kosprysberekening nie maar tot die pryspolitiek. Die bruto winsopslag moet dan dien in die dekking van die konstante en ander koste wat nie in die oorspronklike kosprys opgeneem is nie. Prakties kom dit hierop neer dat iedere kostedraer sy eie bepaalde kosprys het. Dit is met die beskouing van die normatiewe kosprys onmoontlik. Die bedryfspolitiek wat op die gedifferensieerde kosprys gebaseer is, stuit ook op hierdie groot besware.

Slegs in groot uitsonderings sal die differensiële en integrale kosprys saamval. Dis die geval met 'n seisoensonderneming wat met die bestaande produksietoerusting buite die seisoen ander produkte of soortgelyke produkte vir ander afnemers produseer. Die prestasies van die produksietoerusting kan buite die seisoen as vrye werkeenhede beskou word waarvoor geen vergoeding vir die kosprys ingekalkuleer hoef te word nie. In die geval is die integrale en differensiële kalkulasie gelyk. Hierby pas Van der Schroeff se differensiële kostebeskouing in.

Opsommend kan beweer word dat die integrale kostekalkulasie met die differensiële kostebeskouing gebruik kan word, maar dat die integrale of differensiële kostekalkulasie nie bruikbaar is nie.

Met voorafgaande word volstaan aangesien alle fasette onmoontlik nie in die tyd tot my beskikking belig kan word nie.

Ten slotte nog iets oor die toekoms van die beroep van die kostedeskundige. Uit die voorafgaande betoog is dit reeds duidelik dat die kostedeskundige 'n sentrale plek in die onderneming inneem. Derhalwe moet 'n akademiese sowel as ' $n$ professionele opleiding noodsaaklik geag word. Soos die mediese dokters en die tandartse 'n raad het, soos die rekenmeesters deur wetgewing 'n raad ingestel het, so moet die beroep van die kostedeskundige ook beskerm word. So 'n Suid-Afrikaanse 
raad sal die beste waarborg vir die uitbouing van ons professie in die Republiek bied. Dit eis tot 'n baie groot mate spesialisasie aan die universiteit. Daar moet na verdieping en gedurige navorsing van die vakgebied gestrewe word.

Dat die vak op ons hoërskole ontbreek, is ook 'n ernstige belemmering tot die doeltreffendheid van die nywerhede op junior vlak. Dis absoluut noodsaaklik dat die bestaande rade aan hierdie aspek dringende aandag skenk. Die onderwysers wat hulle op die vakgebied bekwaam, neem steeds toe en indien die weg oopgestel word, sal die leerkragte dus in die toekoms gevind kan word. In hierdie opsig staan Suid-Afrika agter by sowel Nederland as Duitsland, waar die vak reeds in die onderwysleerplan opgeneem is.

\section{GERAADPLEEGDE EN AANGEHAALDE LITERATUUR:}

Andriessen, J. E.: De ontwikkeling van de moderne prijstheorie, 2e druk, Leiden, 1961.

Clark, J. M.: Studies in the economics of overhead costs, Chicago, 1923.

Halford, D. R. C.: Differential costs and management decisions, London, 1958.

Horngren, C. T.: Cost accounting, N.Y., 1962.

Institute of cost and works accountants: Report on marginal costing, London, 1958

Kruizinga, H. J.: De organisatiestruktuur van het bedrijf, Leiden, 1953.

Lawrence, F. C. en Humpreys, E. N.: Marginal costing, 1947.

Mey, A.: Beschouwingen over kostenproblemen en resultaten, analyse in de bedrijfshuishoudkunde, Ansterdam, 1961.

Meij, J. L.: Leerboek der bedrijfscconomie, Deel 1, 9e druk, Leiden, 1961.

Prion, W.: Die Lehre von Wirtschaftsbetrieb, Berlyn, (s.j.).

Scholma, C.: Kostencalculatie in het bedrijf, 2e druk, Alphen aan den Rhijn, 1961.

Schroeff, van der H. J.: Leiding en organisatie van het bedrijf, Amsterdam, 1961. De leer van de kostprijs, 4e druk, Amsterdam, 1956.

Shillinglaw, G.: Cost accounting, analysis and control, III, 1962

Slot, R.: Kostenvariabiliteit en variabele kostencalculatie, Leiden, 1962.

Sorgdrager, A. J. E.: Die verbesondering van indirekte koste, Amsterdam, 1961.

Sorgdrager, A. J. E. en Viljoen, F. P.: Leerboek van die moderne kosprysadministrasie, deel I en II, Potchefstroom, 1962.

Spieler, J.: Einlührung und Anleitung zu Wiss'nschaftlichen Denken und Arbeiten, Olten, 1946

Taljaard, J. A. L.: Die mens, die liefde en die sedelike, herdruk uit Koers, 1956.

Thomas, W. E.: Readings in cost accounting, budgetting and control, N.Y., 1956.

Verburg, P.: Economische beslissingselementen in de organisatie, Leiden, 1961.

Walther, A.: Einführung in dic Wirtenschaftlehre der Unternehmung, Zürich, 1947. 